\title{
Retrospective Analysis and Family Feedback of Patients Who Underwent Tracheostomy in Pediatric Intensive Care Unit: Single Center, 10 Years of Experience
}

\section{Çocuk Yoğun Bakımda Trakeostomi Açılmış Hastaların Geriye Dönük Analizi ve Aile Geri Bildirimleri: Tek Merkez, 10 Yıllık Deneyim}

(D) Ülkem KOÇOĞLU BARLAS, iD Hasan Serdar KIHTIR, ib Osman YEŞILBAȘ, iD Mey Talip PETMEZCI, ib Nihal AKÇAY, (i) Esra ŞEVKETOĞLU

1University of Health Sciences, Bakırköy Dr. Sadi Konuk Health Training and Research Hospital, Clinic of Child Health and Diseases, Pediatric Intensive Care, İstanbul, Turkey

\begin{abstract}
Objective: The aim of this study was to investigate the patients who had undergone tracheostomy during hospitalization in our pediatric intensive care unit (PICU), to learn the satisfaction of the families, and to evaluate the effect of tracheostomy on the number of hospitalizations.

Methods: The medical records of 80 patients who underwent tracheostomy in the PICU between 2006-2016 were retrospectively analyzed.

Results: Fourty-one of our patients were male (51.25\%) and 39 were female $(48.75 \%)$. The mean age of males was 46.98 months (1-209 months) and girls was 43.44 months (1-205 months). Neurological system diseases $(42.5 \%)$ were on the first place according to the current chronic diseases. Seventy-five patients (93.75\%) were followed up with invasive mechanical ventilation and the mean duration of mechanical ventilation was $22.47 \pm 13.91$ days. Only one patient $(1.25 \%)$ had complication in early period. Forty one patients were contacted via telephone. Twenty-three families (56\%) were satisfied with tracheostomy and $10(24.5 \%)$ were not. The mean age of the dissatisfied group was statistically lower than the satisfied group $(\mathrm{p}=0.018)$. Of the 41 patients, $18(44 \%)$ reported
\end{abstract}

\section{ÖZ}

\begin{abstract}
Amaç: Bu çalışmada çocuk yoğun bakım birimimizde (ÇYBB) yatarken trakeostomi açılan hastaların incelenmesi, aile memnuniyetlerinin öğrenilmesi ve trakeostominin hastane yatış sayısına etkisinin değerlendirilmesi amaçlanmıştır.

Yöntemler: ÇYBB'de 2006-2016 yılları arasında yatarken trakeostomi açılan 80 hastanın tıbbi kayıtları geriye dönük olarak incelendi. Ailelere ulaşılarak trakeostomiden memnun kalıp kalmadıkları, trakeostomi açılmadan önce ve sonra hastane yatış sayısı arasında fark olup olmadığı ile ilgili bilgi alındı.

Bulgular: Hastalarımızın 41 tanesi erkek (\%51,25), 39 tanesi kızdı (\%48,75). Erkeklerin yaş ortalaması 46,98 ay (1-209 ay), kızların yaş ortalaması 43,44 aydı (1-205 ay). Mevcut kronik hastalıklara göre ilk sırayı nörolojik sistem hastalıkları $(\% 42,5)$ almaktaydı. Yetmiş beş hasta $(\% 93,75)$ invaziv mekanik ventilasyonda takip edilmişti ve mekanik ventilasyonda kalış süreleri ortalama $22,47 \pm 13,91$ gündü. Erken dönemde sadece bir hastada $(\% 1,25)$ komplikasyon gelişmişti. Toplam 80 hastanın 9'u (\%11,25) kaybedilirken 71'i $(\% 88,75)$ eve taburcu edilmişti. Kırk bir hastanın ailesine telefon ile ulaşıldı. Yirmi üç aile (\%56) trakeostomiden memnun olduğunu, 10 aile $(\% 24,5)$ ise memnun olmadığını belirtti. Memnun olmayan grubun yaş ortalaması memnun gruptan istatistiksel olarak a nlamlı
\end{abstract}

Address for Correspondence: Ülkem KOÇOĞLU BARLAS, University of Health Sciences, Bakırköy Dr. Sadi Konuk Health Application and Research Center, Depatment of Child Health and Diseases, Pediatric Intensive Care, İstanbul, Turkey

Phone: +90 5054602645 E-mail: ulkemkocoglu@yahoo.com ORCID ID: orcid.org/0000-0001-7445-5858

Cite this article as: Koçoğlu Barlas Ü, Kıhtır HS, Yeşilbaş O, Petmezci MT, Akçay N, Şevketoğlu E. Retrospective Analysis and Family Feedback of Patients Who Underwent Tracheostomy in Pediatric Intensive Care Unit: Single Center, 10 Years of Experience . Bezmialem Science 2020;8(1):19-25.

${ }^{\circ}$ Copyright 2019 by the Bezmiâlem Vakıf University

Bezmiâlem Science published by Galenos Publishing House.
Received: 08.02.2019

Accepted: 19.03 .2019 
a decrease in the number of hospitalizations between before and after the tracheostomy and four $(10 \%)$ reported an increase in the number of hospitalizations. The group with an increased number of hospitalizations had a significantly higher number of hospitalizations before the tracheostomy ( $\mathrm{p}=0.028)$.

Conclusion: The satisfaction levels of the families will be increased by increasing the tracheostomy care trainings given before discharge from the hospital, improving the home care services and ensuring the ease of transportation of these patients to the hospitals.

Keywords: Child, intensive care, satisfaction, tracheostomy derecede düşüktü $(\mathrm{p}=0,018)$. Ulaşılan 41 hastanın 18’i (\%44) trakeostomi öncesi ve sonrası arasında yatış sayısı bakımından azalma olduğunu, dört hasta (\%10) ise artma olduğunu belirttiler. Yatış sayısı artmış olan grupta trakeostomi açılmadan önce de hastane yatış sayısı yüksek bulundu $(\mathrm{p}=0,028)$.

Sonuç: Taburculuk öncesi verilen trakeostomi bakım eğitimlerinin arttırılması, evde bakım hizmetlerinin geliştirilmesi ve bu hastaların hastanelere ulaşım kolaylığının sağlanması ile ailelerin memnuniyet düzeyleri artacaktır. Trakeostomi açılmadan önce zaten sık hastane yatışı olan hastalarda ise yatış sayısını azaltmak için başka tedbirlerin alınması bu hastalar için daha fazla yarar sağlayabilir.

Anahtar Sözcükler: Çocuk, yoğun bakım, memnuniyet, trakeostomi

\section{Introduction}

Tracheostomy is one of the oldest surgical methods for providing airway clearance (1). The first successful tracheostomy intervention was published by Brassolva in the beginning of $15^{\text {th }}$ century (2). In children, it is most commonly applied in case of prolonged endotracheal intubation due to systemic or upper and lower respiratory diseases in order to reduce sedation time, to relieve mechanical ventilator dependence and thus to increase patient comfort (3). While in the early 1900s, tracheostomy was made in infectious diseases causing upper airway obstruction, nowadays there has been an increase in the number of patients undergoing tracheostomy and change in indications for tracheostomies with the development of intensive care units $(4,5)$.

Telling parents about the need for tracheostomy in appropriate language and getting consent is often one of the most difficult situations we all face. Especially in traditional societies like our country, tracheostomy seems to be a practice that is initially opposed by families. Chen et al. (6)also noted that it is difficult to get families to accept the need for tracheostomy in Taiwan and that this leads to very long periods of invasive and non-invasive mechanical ventilator stays. In this study, we aimed to summarize our 10-year data and to find out what effect tracheostomy has on the quality of life of patients and their parents, whether it reduces the number of hospitalizations of patients and the positivenegative situations experienced by parents in general.

\section{Methods}

This study was carried out in our third level pediatric intensive care unit (PICU) which has a capacity of 16 beds. The study was approved by the Ethics Committee on 11.12.2017 (2017/386). The medical records of 80 of the 86 patients who underwent tracheostomy were retrospectively examined from 2602 patients who were admitted to the PICU between 01.01.2006 and 31.12.2016. Six patients were excluded from the study because their files could not be reached. Patients' ages, genders, current diseases, causes of admission to intensive care unit, number of hospitalizations, mechanical ventilation durations, reintubation numbers, pre-and post-tracheostomy hospitalizations, and early complications were recorded. The patients' families were contacted by telephone to determine whether they were satisfied with the tracheostomy, whether there was a difference between the number of hospitalizations before and after the tracheostomy was opened, and the positive-negative situations they experienced in general.

\section{Statistical Analysis}

In this study, statistical analysis was done with Number Cruncher Statistical System 2007 Statistical Software (Utah, USA) package program. For data analysis, descriptive statistical methods (mean, standard deviation) were used, one way analysis of variance in comparison between groups with variables with normal distribution, independent t-test in binary comparisons between two groups, Kruskal Wallis test in comparisons between groups with variables without normal distribution, Mann-Whitney U test in binary comparisons between groups, and chi-square test in comparisons of quantitative data were used. The results were evaluated at the level of significance $\mathrm{p}<0.05$.

\section{Results}

Of 80 patients, 41 were male $(51.25 \%)$ and 39 were female (48.75\%). Boys' average age was 46.98 months (1-209 months) and girls' average age was 43.44 months (1-205 months). According to the etiology, $34(42.5 \%)$ had diseases of the neurological system; 20 (25\%) skeletal system diseases; nine (11.25\%) congenital metabolic diseases; four (5\%) syndromic conditions; (3.75\%) malignancies; one (1.25\%) trauma; one $(1.25 \%)$ chronic lung disease; one $(1.25 \%)$ hereditary hematologic disorders; one (1.25\%) chronic kidney disease; one $(1.25 \%)$ had infectious disease. Five patients $(6.25 \%)$ were admitted to intensive care unit without any disease. The current diseases of our patients, the reasons for hospitalization, the number of former hospitalizations, the mode of ventilation applied, the number of reintubation, early complications, the location and timing of tracheostomy, discharge and satisfaction are shown in Table 1.

The average duration of stay in mechanical ventilator of 75 patients was $22.47+13.91$ days and the average hospitalization day of our patients before tracheostomy was 24.41 days (3-67 days) and 29.76 days after tracheostomy (1-169 days). 
Table 1. Diagnosis and clinical features of patients undergoing tracheostomy in the pediatric intensive care unit

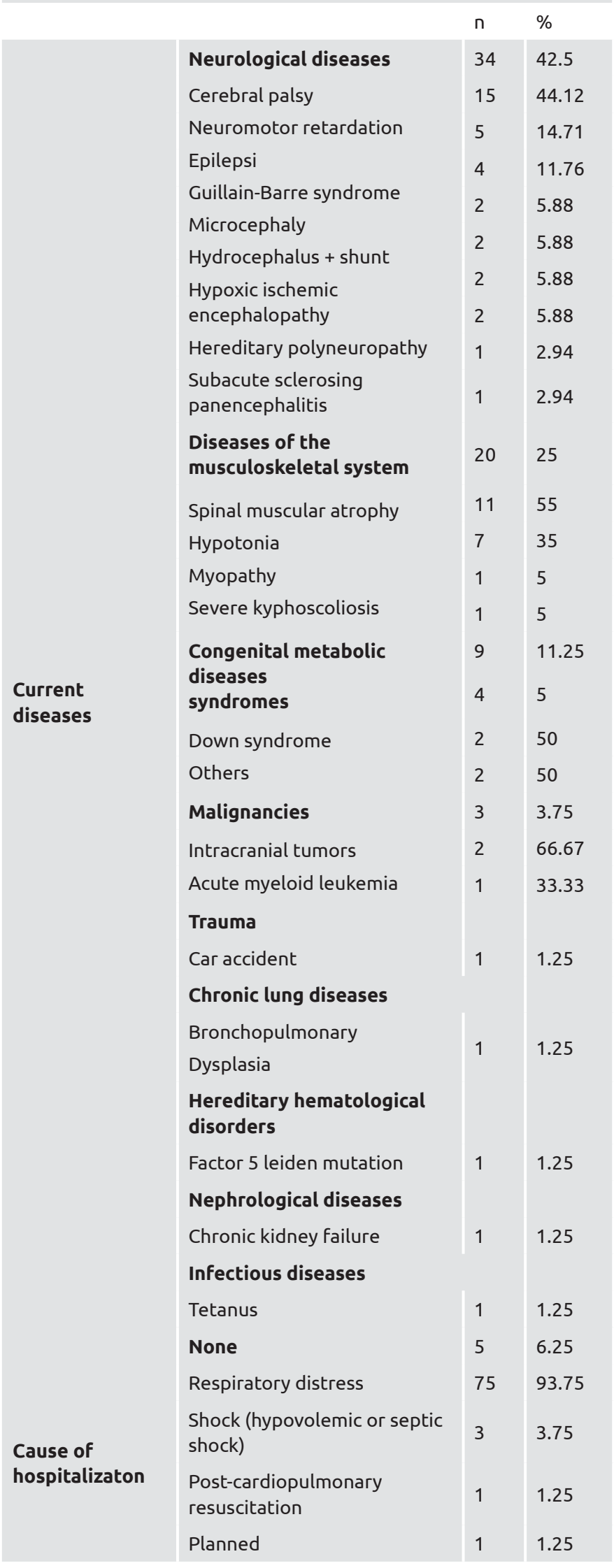

\begin{tabular}{|c|c|c|c|}
\hline \multirow{4}{*}{$\begin{array}{l}\text { Number of } \\
\text { hospitalization }\end{array}$} & None & 27 & 33.75 \\
\hline & 1 & 15 & 18.75 \\
\hline & 2 & 8 & 10 \\
\hline & $>3$ & 30 & 37.5 \\
\hline \multirow{3}{*}{$\begin{array}{l}\text { Mechanical } \\
\text { ventilation }\end{array}$} & Invasive & 75 & 93.75 \\
\hline & Non-invasive & 5 & 6.25 \\
\hline & None & 51 & 63.75 \\
\hline \multirow{3}{*}{$\begin{array}{l}\text { Number of } \\
\text { reintubation }\end{array}$} & 1 & 9 & 11.25 \\
\hline & 2 & 15 & 18.75 \\
\hline & $>3$ & 5 & 6.25 \\
\hline \multirow{2}{*}{ Complication } & No & 79 & 98.75 \\
\hline & Yes & 1 & 1.25 \\
\hline \multirow[t]{2}{*}{ Place and timing } & $\begin{array}{l}\text { Planned/in the operating } \\
\text { room }\end{array}$ & 78 & 97.5 \\
\hline & Emergent/at bedside & 2 & 2.5 \\
\hline \multirow{2}{*}{ Discharge status } & Survived & 71 & 88.75 \\
\hline & Exitus & 9 & 11.25 \\
\hline
\end{tabular}

The families of 41 patients in the study were reached by phone. According to this, eight families (19.5\%) were unable to assess their tracheostomy status after discharge either because they had to be admitted to another intensive care unit or because they had losses shortly afterwards. Twenty-three families $(56 \%)$ said they were satisfied with tracheostomy, while 10 families $(24.5 \%)$ were dissatisfied. The only difference between the dissatisfied and satisfied groups was in mean age. The mean age of the dissatisfied group was statistically significantly lower than that of the satisfied group $(p=0.018)$. There were no statistically significant differences between sex, present disease, cause of hospitalization, number of hospitalizations, duration of hospitalizations before and after tracheostomy, mechanical ventilation and duration, number of reintubation, early complications, location and timing of tracheostomy, and manner of discharge. A comparison of our patients' satisfaction levels is shown in Table 2.

Thirteen of the 41 patients (32\%) were unable to make an assessment due to their initial admission to our service, while 18 patients (44\%) reported a decrease, four patients (10\%) reported an increase and six patients (14\%) reported no changes in terms of number of hospitalizations before and after tracheostomy. The only difference between the declining, increasing, and unchanged groups was in the distribution of the number of hospitalizations before and after tracheostomy. The number of hospitalizations was higher before tracheostomy $(\mathrm{p}=0.028)$ in the group with increased hospitalizations. There were no statistically significant differences between groups in terms of age, sex, current illness, cause of hospitalization, duration of hospitalization before and after tracheostomy, duration of mechanical ventilation, number of reintubation, early complications and satisfaction distributions. The evaluation of the number of hospitalizations before and after tracheostomy in our patients is shown in Table 3 . 
Table 2. Comparison of the satisfaction level of the families whose children underwent tracheostomy

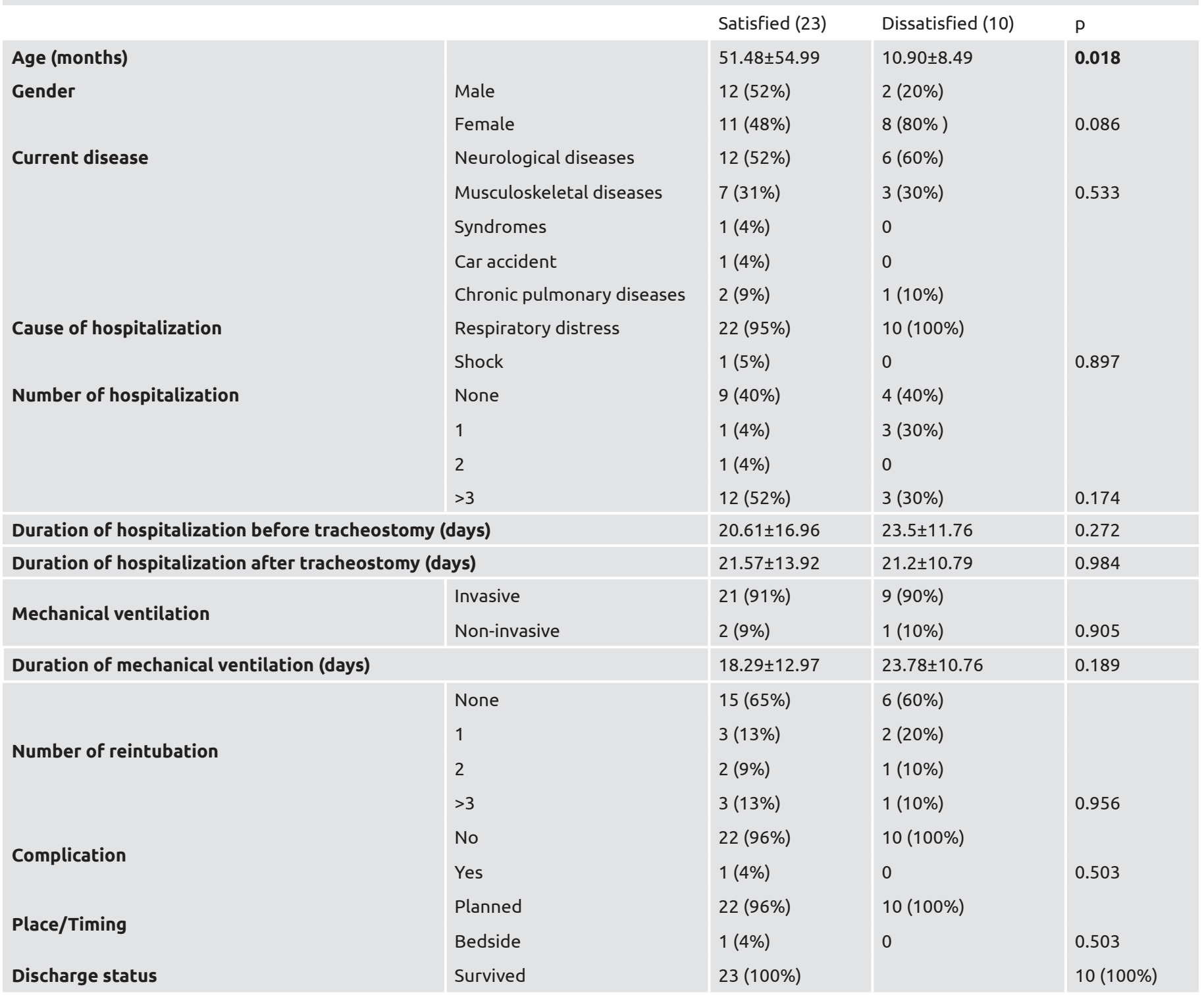

\section{Discussion}

The frequency of performing tracheostomy in intensive care units varies from unit to unit and according to which patients the unit encounters more. Pizza et al. (4) found that the frequency of performing tracheostomy was $1.94 \%$ and we determined our frequency as 3.3\%. In our study, we found in line with the literature that neurological system diseases were the most common disease group in which tracheostomy was performed (7). This is because these children are in the higher risk group in terms of mechanical ventilator duration, ventilator-related pneumonia incidence and mortality rates than other children in intensive care unit (8-10). In 93\% of our patients, the reason for admission to our service was respiratory distress. Since tracheostomy is an application aimed at providing respiratory access, and since the most common two groups of diseases requiring tracheostomy were neurological system and musculoskeletal system diseases, it was considered normal to get this result. In this study, we found high incidence of tracheostomy in children with frequent hospitalizations and high reintubation frequency as well as in children with first-time hospitalization (33.75\%) and first-time intubation (63.75\%).

Tracheostomy is performed in the operating room under normal conditions, under general anesthesia and after intubation $(11,12)$. In our unit, 78 patients $(97.5 \%)$ underwent tracheostomy in elective conditions under operating room conditions and 2 patients $(2.5 \%)$ underwent tracheostomy at the bedside. These two patients were emergency patients who could not be intubated due to difficult intubation. The majority of our patients were in the group of patients we decided to perform tracheostomy due to prolonged mechanical ventilation. There is no conclusive consensus in the literature on the timing of tracheostomy and how long the patient will remain intubated before tracheostomy $(13,14)$. This period varies between 4.3 days and 30.4 days in the United States, with an average of 14.4 days (13-15). In a 1989 
Table 3. Evaluation of the number of hospitalizations before and after tracheostomy

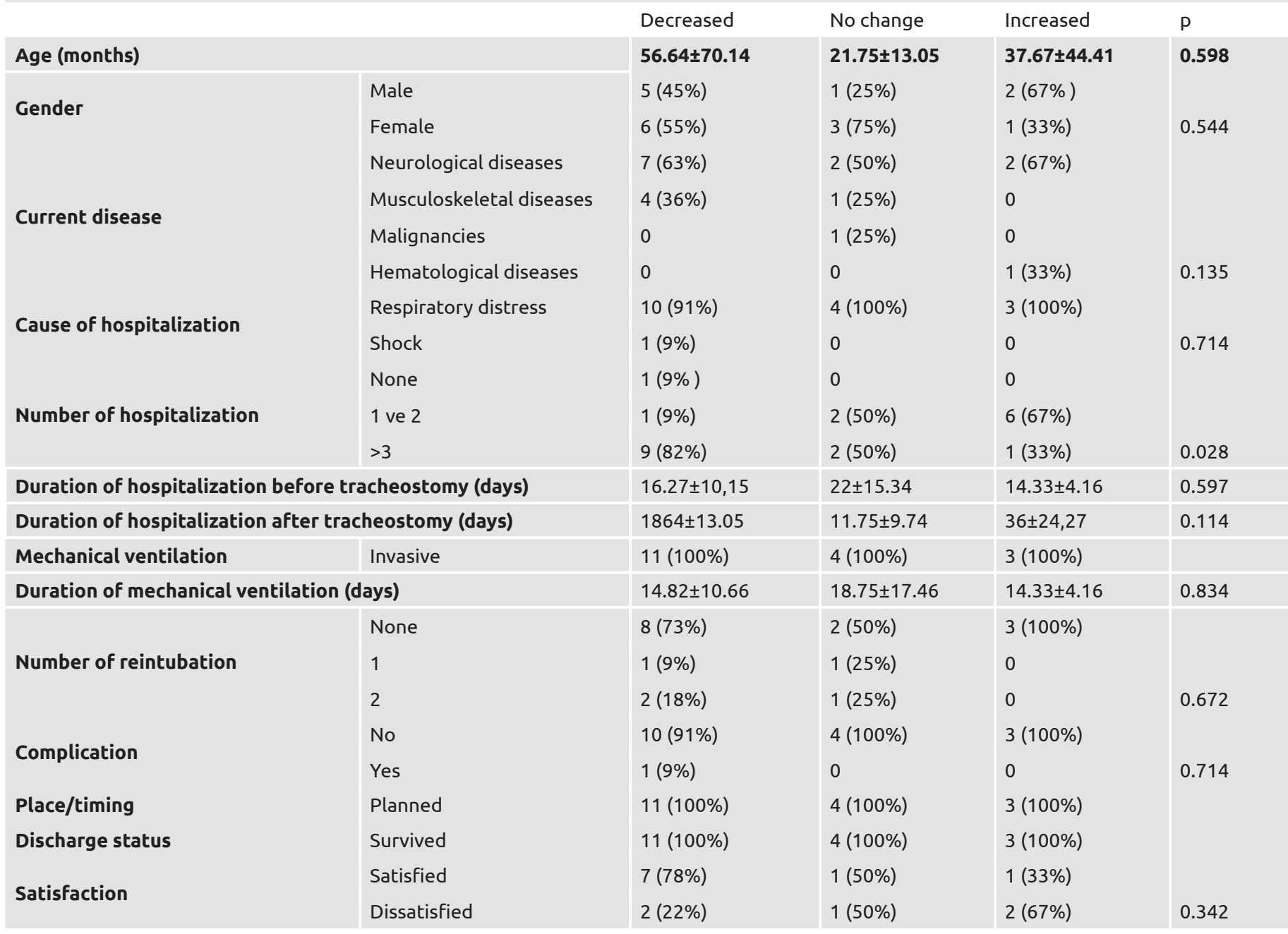

consensus report, The American National Association of Medical Directions of Respiratory Care recommended tracheostomy in patients who have been on a mechanical ventilator for longer than 21 days (16). In children, Holscher et al. (17) and Lee et al. (18) recommended that this period be kept shorter (7 and 14 days) as it provides a decrease in sedation amount, increases in patient comfort and causes a shorter leaving from mechanical ventilator. In the studies from our country, Oğuz and Deniz (19) found the ventilation period before tracheostomy as an average of 30 days and Tolunay et al. (20) found as an average of 29.6 days. The average duration of stay in mechanical ventilator in our patients was $22.47+13.91$ days, the average number of hospitalization days before tracheostomy was 24.41 days (3-67 days) and 29.76 days after tracheostomy (1-169 days).

Early complications such as pneumothorax, pneumomediastinum or subcutaneous emphysema began to decrease with performing of tracheostomy under general anesthesia in operating room conditions (21), but high rates of $53-61 \%$ were reported in some series $(22,23)$. Pneumothorax developed in the early postoperative period in only one patient $(1.25 \%)$ was controlled by early diagnosis and intervention in our study. Mortality rates ranging from $8 \%(24,25)$ to $42.9 \%$ (3) have been reported in the literature associated with underlying disease unrelated to tracheostomy. Deaths due to tracheostomy are below $1 \%(26,27)$. Nine of our patients (11.25\%) were lost due to their underlying diseases, while 71 of them (88.75\%) were discharged to home. There was no mortality due to the tracheostomy procedure.

There are not many studies about the families of children with tracheostomy in the literature. Some surveys to date have shown that the quality of life of parents with children with tracheostomy has decreased, which has a negative impact on the mental health of parents (28). The same surveys highlighted that the stress and fear experienced by parents can be best reduced by communication with experienced families with children with tracheostomy. Margolan noted that only $60 \%$ of parents felt they had received their full pre-discharge tracheostomy training and that they had many concerns (29). Mc Cormick noted that many parents expressed dissatisfaction after discharge and believed that all family members should receive emergency training before being discharged (30). The limitation of our study was that it included patients in the last 10 years and that we did not follow up patients after tracheostomy, so we were able to reach only 41 parents. No surveys could be conducted because we did not meet with the families face to face. However, they were asked to 
make comparisons between the first speech made by us about the necessity of performing a tracheostomy to their children and the period after they started living alone at home after the tracheostomy was performed. In general, they stated that they were satisfied with the tracheostomy and that their fears were lost after they started to live with the tracheostomy, compared to the anxiety and fear they experienced when the first conversation about tracheostomy was made with the families. They explained their levels of satisfaction with decreased complaints about their children's respiratory system, in particular. The dissatisfied group was a particularly small aged group and the reasons for dissatisfaction included inadequate education, difficulty in reaching a hospital when there is a problem, and failure in closing the tracheostomy at follow up. Tracheostomy training is provided by experienced nurses in our unit. However, we believe that establishing tracheostomy training teams, improving the quality of education and providing intermittent home care services to these patients will be better for patient and parental health.

In our study, we found that tracheostomy decreased the number of hospitalizations in $44 \%$ of patients and increased the number of hospitalizations in $10 \%$ of patients. The group with an increased number of hospitalizations was also the group with a higher number of hospitalizations prior to tracheostomy. Although tracheostomy is performed in cases of prolonged mechanical ventilation, it is intended to reduce hospitalizations due to respiratory problems, especially in chronically ill children. However, in these children who are already hospitalized frequently, we believe that the development of respiratory protective methods other than tracheostomy will be more comfortable. After discharge, follow-up of patients with tracheostomy in our hospital is performed by the otorhinolaryngology clinic. The fact that our study covered a period as long as 10 years and that patient follow-up was carried out by another clinic caused the number of patients that could be reached to be limited. Therefore, the satisfaction and hospitalization data after tracheostomy that we aimed for in the study needs to be supported by wider studies.

\section{Conclusion}

Increasing the quality of education given to parents before discharge, especially in the younger age group, and ensuring that these patients have access to hospitals in case of any problem will increase the comfort of life and satisfaction of children and families. In addition, we believe that home care services should be developed and necessary measures should be taken regarding tracheostomy care. In chronic patients who already have frequent hospitalizations, the number of hospitalizations can be reduced by developing other respiratory protective methods.

\section{Ethics}

Ethics Committee Approval: The study was approved by the Ethics Committee on 11.12.2017 (2017/386).

Informed Consent: Our work is retrospective.

Peer-review: Externally peer reviewed.

\section{Authorship Contributions}

Concept: H.S.K., O.Y., M.T.P., Design: Ü.K.B., E.Ş., N.A., Data Collection or Processing: O.Y., N.A., Ü.K.B., Analysis or Interpretation: E.Ş., M.T.P., Ü.K.B., Literature Search: H.S.K., E.Ş., N.A., Writing: M.T.P., Ü.K.B., O.Y.

Conflict of Interest: No conflict of interest was declared by the authors.

Financial Disclosure: The authors declared that this study received no financial support.

\section{References}

1. Ünlü İ, İlhan E, Ünlü EN, Ateş H, Gün E, Yaman H, ve ark. Düzce Üniversitesi Tıp Fakültesi'nde 5 Yıllık Pediatrik Trakeotomi Deneyimimiz. Turk Arch Otorhinolaryngol 2015;53:108-11.

2. Goodall EW. On infectious diseases and epidemiology in the Hippocratic collection: (Section of the History of Medicine). Proc R Soc Med 1934;27:525-34.

3. Acar B, Acar M, Yıldız E, Karaşen RM. Çocuk Trakeostomi: Endikasyonlar, Komplikasyonlar ve 20 Olgunun İncelenmesi. J Turgut Ozal Med Cent 2014;21:41-3.

4. Pizza A, Picconi E, Piastra M, Genovese O, Biasucci DG, Conti G. Early versus late tracheostomy in pediatric intensive care unit: does it matter? A 6-year experience. Minerva Anestesiologica 2017;83:83643.

5. Mok Q. Tracheostomies in paediatric intensive care: evolving indications and changing expectations. Arch Dis Child 2012;97:85859.

6. Chen $\mathrm{CH}$, Chang JH, Hsu CH, Chiu NC, Peng CC, Jim WT, et al. A 12-year-experience with tracheostomy for neonates and infants in northern Taiwan: Indications, hospital courses, and long-term outcomes. Pediatr Neonatol 2018;59:141-6.

7. McPherson ML, Shekerdemian L, Goldsworthy M, Minard CG, Nelson CS, Stein F, et al. A Decade of Pediatric Tracheostomies: Indications, Outcomes, and Long-Term Prognosis. Pediatr Pulmonol 2017;52:946-53.

8. Bell MJ, Carpenter J, Au AK, Keating RF, Myseros JS, Yaun A, et al. Development of a pediatric neurocritical care service. Neurocrit Care 2009;10:4-10.

9. Wainwright MS, Grimason M, Goldstein J, Smith CM, Amlie-Lefond C, Revivo G, et al. Building a pediatric neurocritical care program: a multidisciplinary approach to clinical practice and education from the intensive care unit to the outpatient clinic. Semin Pediatr Neurol 2014;21:248-54.

10. Al harfi IM, Charyk Stewart T, Al Helali I, Daoud H, Fraser DD. Infection rates, fevers, and associated factors in pediatric severe traumatic brain injury. J Neurotrauma 2014;31:452-58.

11. Ünal F. Tracheostomy in children. Pediatrik Kulak Burun Boğaz Hastalıkları II. Katkı Pediatri Dergisi 2004;26:48-54.

12. Akcan AB, Dursun O. Pediatrik trakeotomi ve ev bakımı. KBBForum 2010;9:70-7.

13. Wood D, McShane P, Davis P. Tracheostomy in children admitted to paediatric intensive care. Arch Dis Child 2012;97:866-9. 
14. Principi T, Morrison GC, Matsui DM, Speechley KN, Seabrook JA, Singh RN, et al. Elective tracheostomy in mechanically ventilated children in Canada. Intensive Care Med 2008;34:1498-502.

15. Wakeham MK, Kuhn EM, Lee KJ, McCrory MC, Scanlon MC. Use of tracheostomy in the PICU among patients requiring prolonged mechanical ventilation. Intensive Care Med 2014;40:863-70.

16. Plummer AL, Gracey DR. Consensus conference on artificial airways in patients receiving mechanical ventilation. Chest 1989;96:178-80.

17. Holscher C, Stewart C, Peltz E, Burlew CC, Moulton SL, Haenel JB, et al. Early tracheostomy improves outcomes in severely injured children and adolescents. J Pediatr Surg 2014;49:590-2.

18. Lee J, Koo C, Lee S, Kim EH, Song IK, Kim HS, et al. Effect of early vs late tracheostomy on clinical outcomes in critically ill pediatric patients. Acta Anaesthesiol Scand 2016;60:1281-88.

19. Oğuz D, Deniz O. Early and long-term outcome after tracheostomy in children. Pediatr Int 2011;53:202-6.

20. Tolunay İ, Yıldızdaş RD, Horoz ÖÖ, Sürmelioğlu Ö, Ekinci F, Petmezci E, ve ark. Çocuk Yoğun Bakım Ünitemizde Trakeostomi Açılan Hastalarımızın Değerlendirilmesi. J Pediatr Emerg Intens Care Med 2015;2:61-4.

21. Watters KF. Tracheostomy in Infants and Children. Respir Care 2017;62:799-825.

22. Carr MM, Poje CP, Kingston L, Kielma D, Heard C. Complications in pediatric tracheostomies. Laryngoscope 2001;111:1925-8.
23. Carron JD, Derkay CS, Strope GL, Nosochuk JE, Darrow DH. Pediatric tracheostomies: changing indications and outcomes. Laryngoscope 2000;110:1099-104.

24. Berry JG, Graham DA, Graham RJ, Zhou J, Putney HL, O’Brien JE, et al. Predictors of clinical outcomes and hospital resource use of children after tracheostomy. Pediatrics 2009;124:563-72.

25. Lewis CW, Carron JD, Perkins JA, Sie KC, Feudter C. Tracheostomy in pediatric patients: a national perspective. Arch Otolaryngol Head Neck Surg 2003;129:523-9.

26. Rozsasi A, Kühnemann S, Gronau S, Keck T. A single-center 6-year experience with two types of pediatric tracheostomy. Int J Pediatr Otorhinolaryngol 2005;69:607-13.

27. Dutton JM, Palmer PM, Mc Culloch TM, Smith RJ. Mortality in pediatric patient with tracheostomy. Head Neck 1995;17:403-08.

28. Joseph RA, Goodfellow LM, Simko LM. Parental quality of life: caring for an infant or toddler with a tracheostomy at home. Neonatal Netw 2014;33:86-94.

29. Margolan H, Fraser J, Lenton S. Parental experience of services when their child requires long-term ventilation: implications for commissioning and providing services. Child Care Health Dev 2004;30:257-64.

30. McCormick ME, Ward E, Roberson DW, Shah RK, Stachler RJ, Brenner MJ. Life after Tracheostomy: Patient and Family Perspectives on Teaching, Transitions, and Multidisciplinary Teams. Otolaryngol Head Neck Surg 2015;153:914-20. 